Working Paper 9605

\title{
ENDOGENOUS MONEY SUPPLY AND THE BUSINESS CYCLE
}

by William T. Gavin and Finn E. Kydland

William T. Gavin is vice president and research coordinator at the Federal Reserve Bank of St. Louis, and Finn E. Kydland is a professor of economics in the Graduate School of Industrial Administration at Carnegie-Mellon University and a research associate at the Federal Reserve Bank of Cleveland. For helpful comments and suggestions, the authors thank David Altig, Mike Bryan, Mike Dotsey, Milton Friedman, Kevin Lansing, Mike Pakko, Joe Ritter, Ben Russo, and seminar participants at the University of Texas, Cornell University, Brigham Young University, and the Federal Reserve Banks of Dallas, Richmond, and St. Louis.

Working papers of the Federal Reserve Bank of Cleveland are preliminary materials circulated to stimulate discussion and critical comment. The views stated herein are those of the authors and not necessarily those of the Federal Reserve Banks of Cleveland or St. Louis, or of the Board of Governors of the Federal Reserve System.

Working papers are now available electronically through the Cleveland Fed's home page on the World Wide Web: http://www.clev.frb.org.

July 1996 


\begin{abstract}
$\underline{\text { Abstract }}$
This paper documents changes in the cyclical behavior of nominal data series that appear after 1979:IIQ, when the Federal Reserve implemented a policy to end the acceleration of inflation. Such changes were not apparent in real variables. A business cycle model with impulses to technology and a role for money is used to show how alternative money supply rules are expected to affect observed business cycle facts. In this model, changes in the money supply rules have almost no effect on the cyclical behavior of real variables, yet have a significant impact on the cyclical nature of nominal variables. Computational experiments with alternative policy rules suggest that the change in monetary policy in 1979 may account for the sort of instability observed in the U.S. data.
\end{abstract}




\section{Introduction}

One of the main ideas to come out of real business cycle theory is that a significant share of the variation in the real economy can be accounted for in a simple economic model of production and consumption that abstracts from money. The credibility of this finding is, in some way, associated with the relative stability of the covariance structure of real aggregate datá across time and countries, as documented by Backus and Kehoe (1992). The relative constancy of the business cycle facts guides model development.

Unfortunately, attempts to include money and inflation do not have this advantage. When money and prices are added to the data series, the covariance structure becomes unstable and the search for a monetary structure becomes more complicated. Backus and Kehoe present evidence contrasting the stability of the covariance structure of real data series with the instability in the cyclical behavior of money and prices. They use annual data to compare the correlations measured across three periods: before World War I, the interwar period, and post-World War II. Further evidence on the instability of the output-price correlations can be found in Cooley and Ohanian (1991), Smith (1992), and Wolf (1991). In this paper, we use postwar quarterly data to document the changes in the nominal data series that are apparent after October 1979, and to show how a shift in the money supply rule may account for such instability. ${ }^{1}$

The first part of the paper describes the business cycle facts. There appears to be an important break in the covariance structure in 1979:IIIQ, when the Federal Reserve implemented a policy to end the acceleration of inflation. ${ }^{2}$ We present Wald statistics suggesting that the changes in cyclical behavior are significant. Because there is some doubt about whether the distributional assumptions underlying the Wald tests are valid, we also use 
Monte Carlo methods to construct small-sample test statistics, which provide strong evidence of a break in the cyclical behavior of money and prices about the time of the Fed's policy change.

The second part of the paper experiments with alternative money supply rules in a business cycle model with impulses to technology. In this model, the cyclical nature of the nominal variables is highly sensitive to small changes in the decision rule governing the money supply. However, such changes have almost no impact on the cyclical behavior of the real variables. Finally, we present the results of experiments which suggest that attempting to increase control over the money supply may account for the sort of changes we document.

\section{The Facts}

We begin by updating some of the business cycle facts presented in Kydland and Prescott (1990). The Hodrick-Prescott filter was used to define the business cycle components of the data series. The first column of statistics in table 1 reports the percentage standard deviation of each variable, and the other columns report the cross-correlations with real GDP. The statistics reported in Kydland and Prescott use data for a different sample than is used here. For GNP components and price data, their sample period begins in 1954:IQ and ends in 1989:IVQ. Their sample for the monetary data begins in 1959:IQ. We use a sample of data from 1959:IQ through 1994:IVQ. Instead of GNP, we follow current government practice and switch to GDP data. Despite these differences in data and time periods, our reported correlation coefficients are, in most cases, virtually identical to those reported by Kydland and Prescott. The components of consumption and investment are highly procyclical. Consumption of nondurables and services is less variable than output, while 
expenditures on durables and all the components of investment are much more variable than output, in percentage terms.

Like the real variables, the statistics reported for the price level and money supply measures in table 2 also appear to have nearly the same variability and cross-correlation with real output growth as reported by Kydland and Prescott. In the case of both the GDP deflator and the CPI, the business cycle regularities over the full sample show that prices move countercyclically. The monetary base varies procyclically and contemporaneously with output, while M1 and M2 move procyclically and lead output by a quarter or two. Measures of velocity also move procyclically. Base velocity tends to move coincidentally, while the velocity of M1 and M2 lag the cycle in real GDP.

Taken as a whole, the statistics show little change with the addition of five years. However, if we break the sample after 1979:IIIQ, we see a significant change in some of the facts. The real variables are apparently unaffected, but the correlation between real output and the nominal variables is altered dramatically. We should note that one real variable, velocity, also appears to behave differently across the two periods. In general, we include velocity with the monetary variables because the demand for real balances may depend on the money supply rule.

Table 3 reports the results for the real variables when we treat 1979:IIIQ as a breakpoint in the data. It was at the end of this quarter that the Federal Reserve announced a major change in operating procedures and a new commitment to reducing the inflation rate through controlling the money supply. Apparently, this policy change had almost no measurable effect on the cyclical behavior of hours worked or on the components of consumption and investment. 
In contrast to the results for the real variables shown in table $\$$, the business cycle facts for prices and money shown n table 4 are different in the two periods. The variability of the price measures is similar across periods. However, the negative cross-correlations between the deflator and real GDP become much larger in absolute value for leads of three to five quarters. The absolute value of the contemporaneous and leading correlations falls. The differences ackoss periods for the GDP deflator are similar to differences observed in the CPI.

Substantial changes occur in the variability of the monetary aggregates around trend. The narrow monetary aggregates -- the monetary base and M1 -- are less variable before 1979:IIIQ than afterward, while the broad monetary aggregate, M2, becomes less variable after 1979:IIIQ. All of the aggregates appear to be less procyclical in the second period than in the first. The contemporaneous correlation of the monetary base with real GDP falls about one-fourth, from 0.46 to 0.34 . The contemporaneous correlations of M1 and M2 drop dramatically, from 0.71 to 0.18 and from 0.64 to -0.04 , respectively.

To test whether changes in the correlation coefficients are statistically significant, we construct a Wald test to compare the null hypothesis that the correlation coefficient in the latter period is equal to the correlation coefficient in the earlier period against the alternative that they are not equal. ${ }^{3}$ If one assumes that the two variables are a random sample drawn from a bivariate normal distribution, then the Wald statistic is distributed as a Chi-square with one degree of freedom. The 10 percent critical value is 2.71 .

Table 5 reports the Chi-square statistics for the real variables, including the results of testing 77 cross-correlations between real GDP and the other real variables across the two periods. Only in two cases (highlighted in the table) do the calculated statistics exceed the 10 percent critical value. In contrast, the top panel of table 6 reports the results for 55 cross- 
correlations calculated between real GDP and the nominal variables. Here, 33 of the 55 are above the 10 percent critical value. For every nominal variable, at least part of the crosscorrelation structure is significantly different after 1979:IIIQ. The bottom panel of table 6 includes results for the velocity variables. Here, 20 of 33 statistics exceed the 10 percent critical value of 2.71. Of course, we cannot be sure how much the actual data differ from the maintained assumptions of the Wald test. However, our main point is simply to emphasize the difference between the nominal and real cases.

We provide some check on the reliability of the Wald test by constructing simulated critical values from 1,000 repetitions of the following experiment. Using actual data from 1959:IQ to 1979:IIIQ (not deviations from trend), we estimate a bivariate vector autoregression that includes real GDP and one of each of the other variables. In every case, we recover estimates of autoregressive parameters and the covariance matrix, which are then used with a random number generator to create 1,000 artificial series for each pair. These series are then detrended, the sample split at 1979:IIIQ, and the cross-correlations calculated. For each artificial series, the Wald test is constructed to determine stability across the two periods. The 1,000 tests are sorted by size, and the one-hundredth largest is reported in parentheses in tables on and

Use of the simulated critical value makes the two rejections for the real data no longer significant (seetable s). In the case of the nominal variables and velocity shown it table 6 , the number of significant changes drops from 33 to 20 out of 55 . For the velocity measures, we find that 12 of the 33 tests reject the null hypothesis. Even though there is a reduction in the number of rejections using the Monte Carlo method, an overwhelming difference in the cyclical stability of real versus nominal variables remains. 


\section{A Model of Aggregate Fluctuations with Monetary Policy}

The model used here -- a modification of a monetary model developed by Kydland (1991) to examine the role of money in business cycles -- is based on a neoclassical growth model with technology shocks. It includes a time-to-build technology for producing consumer durables, which affect the ability and willingness of households to substitute intertemporally. In each period, the consumer decides how to allocate time between work and leisure. Larger money balances increase the amount of time that can be allocated to these two activities. Money enters the economy as a government transfer. In Kydland, the money supply is treated as an exogenous univariate process. In this paper, the money supply function also depends on last period's output. This extension allows us to investigate the implications of a central bank's decision about whether to focus more sharply on nominal or real variables.

\section{The Economy}

The model economy is inhabited by many households that are all alike. Their available time, $\mathrm{T}$, is spent in three basic activities: input in market production, leisure, and transaction-related activities such as trips to the bank, shopping, and so on. The role of money is to make the third activity less time consuming. By holding larger money balances, households have more time for work and/or leisure. Assume that the time spent on transactions-related activities in period $\mathrm{t}$ is given by the expression

$$
\omega_{n}-\omega_{1}\left(p_{t} m_{t}\right)^{\omega_{2}}
$$


where $\omega_{0}>0, \omega_{1}>0,0<\omega_{2}<1, m_{t}$ is the nominal money stock, and $p_{t}$ is the price of money relative to that of physical goods. Thus, the amount of time saved increases as a function of real money holdings, but at a decreasing rate. ${ }^{4}$ Leisure in period $t$, then, is

$$
\ell_{t}=T-n_{t}-\omega_{0}+\omega_{1}\left(p_{t} m_{t}\right)^{\omega_{2}}
$$

where $n_{t}$ is time spent in market production. Without loss of generality, we choose units so that $\mathrm{T}-\omega_{0}$ equals one.

Each household maximizes

$$
E \sum_{t=0}^{\infty} \beta^{\mathrm{t}} \mathrm{u}\left(\mathrm{c}_{\mathrm{t}}, \mathrm{d}_{\mathrm{t}}, \mathrm{l}_{\mathrm{t}}\right)
$$

where $\mathrm{c}$ is consumption, $\mathrm{d}$ is the stock of durables (the services of which are proportional to the stock), and $0<\beta<1$ is a discount factor. The functional form of the current-period utility function is

$$
u\left(c_{t}, d_{t}, l_{t}\right)=\left[c_{t}^{\mu} d_{t}^{\theta} l_{t}^{1-\mu-\theta}\right]^{1-\gamma} /(1-\gamma)
$$

where $\mu, \theta$, and $\gamma$ are positive parameters, with $\mu+\theta<1$. This special case of the CES function, with unitary substitution elasticities among the goods, was chosen for two reasons. First, within this class, it is consistent with long-run hours worked per person being roughly constant (as in postwar U.S. data), despite the large increase in real hourly compensation. Second, unitary elasticity between consumer durables and nondurables is evidenced by the fact that the long-run share of nominal expenditures on durables has remained essentially 
constant in the postwar period, in the face of a sizable decline in their relative price.

The time-to-build specification of Kydland and Prescott (1982) is applied to consumer durables. Stocks of finished and unfinished consumer durables are governed by the laws of motion,

$$
\begin{aligned}
& d_{t+1}=(1-\delta) d_{t}+s_{1 t}, \\
& s_{j, t+1}=s_{j+1, t}, j=1, \ldots, J-1,
\end{aligned}
$$

where $0<\delta<1$ is the depreciation rate and $s_{\mathrm{lt}}$ is the addition to the stock of durables initiated in period $\mathrm{t}-\mathrm{J}+1$. Suppose additions to durables planned in period $\mathrm{t}$ do not start producing services until period $t+J$, as expressed by the two relations above. The expenditures, however, are distributed with a fraction $\phi_{\mathrm{j}}$ in the $\mathrm{jth}$ stage from the last for all $\mathrm{j}$. Formally, then, total expenditures on durables in period $t$ are

$$
\mathrm{x}_{\mathrm{t}}=\sum_{\mathrm{j}=1}^{\mathrm{J}} \phi_{\mathrm{j}} \mathrm{s}_{\mathrm{jt}}, \quad \text { where } \sum_{\mathrm{j}=1}^{\mathrm{J}} \phi_{\mathrm{j}}=1
$$

The budget constraint for the typical individual is $c_{t}+x_{t}+p_{t} m_{t+1}=w_{t} n_{t}+p_{t} m_{t}+p_{t} v_{t}$, where $v_{t}$ is a nominal lump-sum transfer from the government.

Aggregate output, $Y_{t}$, is given by the product of the labor input and aggregate productivity: $Y_{t}=Z_{1} N_{t}$. In equilibrium, the real wage rate, $w_{t}$, will equal the level of productivity, which changes over time according to

$$
Z_{t+1}=\rho Z_{t}+\lambda_{t+1} \text {, where } 0<\rho<1 .
$$

The innovations are assumed to be normally distributed with positive mean and variance $\sigma_{\lambda}^{2}$. Laws of motion analogous to those of individual variables govern the aggregate quantities of durables and the addition to the stock of durables initiated in each period. The 
distinction between individual and aggregate variables, represented here by lower- and upper-case letters, respectively, plays a role when computing the equilibrium of models in which the equilibrium is not simply the solution to a stand-in planner's problem. In particular, this is true in models with government policy. The details are available in Kydland (1989).

\section{Steady State and Calibration}

We use a priori knowledge to quantify most parameters, such as capital depreciation rates, capital-output ratios, weights on lags in durable expenditures, steady-state time allocation, and so on. Such restrictions are easily imposed within this framework and, in principle, leave no free parameters, although accurate measurements are not necessarily available for all of them at this point.

To obtain the steady state, we first substitute for $c_{t}$ from the budget constraint into the utility function. Omitting time subscripts for steady states, we have (because $x=s$ )

$$
\mathrm{c}=\mathrm{wn}-\mathrm{x} \text {. }
$$

We also have $\mathrm{x}=\delta \mathrm{d}$.

If there is no lag in the production of durables, that is, $\mathrm{J}=1$, then the implicit steady-state rental price $q$ of durables in terms of nondurables is $r+\delta$, where $r$ is given by $1 /(1+r)=\beta$. If, on the other hand, it takes time to produce durables, then this price becomes

$$
q=(r+\delta) \sum_{j=1}^{J}(1+r)^{j-1} \phi_{j}
$$

To determine relations between the steady-state values of $c, d$, and $n$ on the one hand, 
and values of the parameters $\mu$ and $\theta$ on the other, suppose first that the sum of services from nondurables and durables is $c+q d$. Then, from the condition $M U_{q} / M U_{c}=w$, one obtains

$$
(1-\mu-\theta) / \ell=(\mu+\theta) w /(c+q d)
$$

Using $\ell=1-\mathrm{n}+\omega_{1}(\mathrm{pm})^{\omega_{2}}, \quad$ this condition can be rewritteri as

$$
\mu+\theta=\frac{c+q d}{c+q d+\left[1-n+\omega_{1}(p m)^{\omega_{2}}\right] w} .
$$

The values of $\mu$ and $\theta$ now follow from the condition

$$
\frac{\mu}{\theta}=\frac{c}{q d}
$$

Finally, the first-order condition with respect to money can be solved for steady-state pm in terms of the given parameters. Steady-state $p$, then, is implied by the assumed steadystate nominal money stock, $\mathrm{m}$.

The model is calibrated as follows. The discount factor $\beta$ is chosen such that $(1-\beta) / \beta=r=0.01$, corresponding to a 4 percent annual real rate of interest. The depreciation rate of durables is set to 0.05 . The value of $\gamma$ is two, which means more curvature on the utility function than that corresponding to logarithmic utility. This value is consistent with the empirical findings of Neely, Roy, and Whiteman (1995).

Steady-state $n$ is set equal to 0.3 . This value is the household's share of the time T- $\omega_{0}$ allocated to market activity. Although we do not have any independent measurements of $\omega_{0}$, it is probably small in relation to total time $T$. The value for $n$, then, is in line with the measurements of Ghez and Becker (1975). 
The share of output going to investment in durables is 0.3 , corresponding roughly to the fraction spent on producer and consumer durables in the United States. From these values, it follows that $\mu=0.20$ and $\theta=0.10$. Average $Z$ (and therefore $w$ ) is chosen so that steady-state output is one. The value of $J$, the time needed to build durables, is set equal to three, and the values of $\phi_{1}, \phi_{2}$, and $\phi_{3}$ are one-third. Consistent with the evidence that changes in the technology level are long-lived (see, for example, Prescott [1986]), the autocorrelation parameter $\rho$ is set equal to 0.95 .

The values assumed for $\omega_{1}$ and $\omega_{2}$ are 0.0065 and 0.50 , respectively. These magnitudes can be understood through a marginal evaluation around the average. If the real money stock, pm, is increased 1 percent relative to its steady state, then a household's resulting weekly time saving is less than a minute. The implied steady-state velocity is 5.3 , which corresponds to average M1 velocity since 1959 . Without loss of generality, steadystate nominal money stock is chosen to equal one, and the price level, $\mathrm{p}$, is then determined accordingly.

The model economy we use in our computational experiments is a quadratic approximation around the steady state. The resulting structure fits into the general framework outlined in Kydland (1989), and the dynamic competitive equilibrium is computed as described there.

\section{Monetary Policy}

We modify the basic model to include a monetary policy function that changes the money supply growth rate in response to last period's level of output and the money supply. The alternatives we examine are all specific instances of the following general rule: 


$$
M_{t+1}-M_{t}=v_{0}+v_{1} Y_{t-1}+v_{2} M_{t}+\epsilon_{t}
$$

where $v_{1}$ is the proportional response to last period's output level, $v_{2}$ is the response to the money stock, and $\epsilon_{\mathrm{t}}$ is the money supply shock in period t. If both $v_{1}$ and $v_{2}$ are 0 , the money supply is a random walk. One way to judge the magnitude of the $v_{i}$ 's is to note that the steady-state values of $\mathrm{Y}$ and $\mathrm{M}$ are both one. We do not estimate or calibrate the policy function in this paper. Recent work by Salemi (1995) suggests that, in future research, we may be able to calibrate the various policy rules that were in effect in the United States in the postwar period. In this paper, we merely show that the quantitative implications of alternative policy rules on the nominal-to-nominal and nominal-to-real correlations can be large.

Table 7 includes cyclical statistics calculated from the model economy with a fixed money stock; that is, with the $v_{\mathrm{i}}$ 's and the variance of $\epsilon$ equal to 0 . Like the U.S. economy, our model generates components of consumption and investment that are highly procyclical. In percentage terms, consumption of nondurables and services is less variable, and expenditures on durables are much more variable, than output. The price level (conventionally measured) is countercyclical. The cyclical standard deviation of the price level is 0.67 , a little lower than the average standard deviation of the GDP deflator in the U.S. data $(0.87$ for the full sample [seetable 2]). Without the lag in the production of durables, the price fluctuation is somewhat smaller. Velocity in the model moves procyclically.

With no money-stock variability, the price fluctuation in this model is below that observed in U.S. data. Still, the benchmark of a constant money stock (interpreted as a constant growth rate) produces variability in the price level that is more than half of output 
variability. The first row of table $\$$ repeats statistics from the benchmark case. When the benchmark assumptions are changed by increasing the variance of the money supply shock, the cyclical standard deviation of the price level increases. Row four shows that when the standard deviation of the money supply shock is increased from 0 to 9.60 percent, the standard deviation of the price level rises to 1.11 percent, that of velocity increases from 0.58 to 0.85 percent, and the contemporaneous correlation coefficient between the conventional price level and output becomes -0.57 , close to that in U.S. datá.

Table \& also reports selected statistics from experiments involving alternative policy rules. One might think of the money supply error as a policy control error. Even if this error is set to 0 , allowing money growth to be correlated with output induced realistic levels of variability in the nominal variables. This can be seen in the second row (case II). Compared to the benchmark case in row one, the variance of the price level increases and the behavior of the price level switches from highly countercyclical to highly procyclical. The variance of the money stock is driven by the variance in output. As can be seen in both cases II and VI, allowing money growth to depend on output this way causes velocity to be highly variable and strongly procyclical.

In case III, the money supply error variance is set to 0 and $v_{1}$ is set to 0.10 , as in case II, but $v_{2}$ is lowered to -0.05 , so that the money stock is stationary. This change reduces price variability by about half, causes the price level and inflation to become countercyclical, and induces a switch in the sign of the correlation between money growth and inflation.

In the fifth row, we report the results of the experiment when money supply growth responds to the level of the money stock but not to output. The most important effect is the reduction of the contemporaneous correlation between inflation and money growth that was 
induced by the introduction of uncertainty into the money supply process ( 0.77 in case IV).

In the last two experiments, we leave the variance of the money shock at 0.6 percent and set $v_{1}$ to 0.1 . We set $v_{2}$ equal to 0 in case VI and to -0.05 in case VII. Adding variance to the money shock when money growth is tied to past output increases the variability of both money and the price level. Adding this variance also induces a strong positive correlation between inflation and money growth. As shown in row seven, moving away from a unit root in the money supply process also makes a substantial difference in the results. Most noticeable are the reduction in the standard deviation of the price level from 1.22 to 0.48 , and the switch in the sign of the correlation between output and the price level from 0.73 to -0.90 . Setting $v_{2}$ equal to -0.05 also changes the sign on the correlation between inflation and output and reduces the correlation of money growth and inflation.

To summarize the main results in table 8 , we find that changes in the money supply process could have significant effects on both the variability of the price level and the size and sign of the correlation between the price level and output. The size and sign of the inflation/output correlations and the inflation/money growth correlations depend on the size of the policy parameters. The variability of velocity is also quite sensitive to alternative policy specifications.

Next, we look more closely at price-output, inflation-output, and inflation-money growth correlations. Figure 1 shows the effect of varying the response to output, $v_{1}$, from 0 to 0.2 while holding the response to the money supply, $v_{2}$, at -0.02 . Setting $v_{1}$ to 0 results in a strong negative correlation between the price level and output $\left(\sigma_{\mathrm{p}, \mathrm{y}}\right)$. As $v_{1}$ is raised to 0.15 , the correlation coefficient rises toward 0 , and with $v_{1}$ at $0.2, \sigma_{p, y}$ becomes greater than onehalf. The inflation-output correlation $\left(\sigma_{\mathrm{dp}, \mathrm{y}}\right)$ follows the same general pattern as $\sigma_{\mathrm{p}, \mathrm{y}}$. Figure 1 
also shows how the contemporaneous correlation between inflation and money growth $\left(\sigma_{\mathrm{dm}, \mathrm{dp}}\right)$ changes as the policy response to output is varied. Here, $\sigma_{\mathrm{dm}, \mathrm{dp}}$ is small and positive when $v_{1}$ equals 0 , rises to a peak when $v_{1}$ is around 0.15 , and declines as $v_{1}$ is increased further.

Figure 2 shows how the correlations change when we vary the policy response to the money stock, $v_{2}$, while holding the response to output, $v_{1}$, at 0.1 . The negative correlation between output and the price level rises toward 0 as $v_{2}$ is raised from -0.05 toward 0 . Most of the change in the correlation occurs after $v_{2}$ is raised above -0.02 . The same pattern emerges in the correlation between inflation and output. The contemporaneous correlation between inflation and money growth rises to a peak as $v_{2}$ is raised from -0.05 to about -0.01 . It then declines as $v_{2}$ is increased to 0 .

These dramatic changes in the covariance structure of the nominal series occur in a model in which the monetary rule has almost no impact on the real variables. Of all the real variables, hours worked is the most affected by the alternative monetary regimes. Even so, the results are not shown here because the differences are not apparent at two significant digits. We also experimented with alternative specifications of the business cycle model, including versions with a shorter time-to-build for durable goods. In all cases, the results are basically the same as for the specification presented in this paper: Changes in the monetary policy rule have large effects on the correlations among nominal variables and on the crosscorrelation structure between nominal and real series, without having any noticeable impact on the real variables. 


\section{Conclusion}

The behavior of money and prices over the business cycle defies simple classification in empirical regularities. We document the relative instability of the behavior of nominal variables vis-à-vis the behavior of real variables. Looking at the stability of crosscorrelations between real GDP and each of seven real variables -- personal consumption expenditures, expenditures on nondurables and services, expenditures on consumer durables, private domestic investment, fixed investment, hours worked, and productivity -- we found that only in two of 77 cases did the $\chi^{2}$ statistic reject the null hypothesis of stability at the 10 percent critical level. When we constructed Monte Carlo estimates of the statistic's distribution, even those two rejections were overturned. The result for the nominal variables -- the GDP deflator, CPI, monetary base, M1, and M2 -- was much different. In this case, we were able to reject stability in 33 of 55 cases using the 10 percent critical region of the asymptotic distribution. When we used the simulated critical values, the number of rejections dropped to 20 .

In the second part of the paper, we explore the possibility that the instability in the cyclical behavior of the nominal data is caused by instability in the money supply function. We modify a real business cycle model with time-to-build consumer durables and a laborleisure trade-off by adding a time-saving role for money balances. We also include a monetary policy function that could react to both real output and the money supply. In a variety of experiments testing the sensitivity of the model to the policy function parameters, we find that the cross-correlations of nominal variables with real GDP, and the crosscorrelations of inflation with lagged money growth, are sensitive to the specification of the

policy rule. Whether the price level is procyclical or countercyclical depends importantly on 
whether the money stock is allowed to react to real factors and to the amount of persistence that the authorities induce in money supply shocks. These findings are obtained in a model in which the specification of the monetary rule has almost no impact on the cyclical behavior of real variables. 


\section{Endnotes}

1. Bryan and Gavin (1994) show how the change in the money supply rule in 1979:IIIQ might explain the change in the cross-correlation between inflation and monetary base growth that occurred about that time.

2. Rolnick and Weber (1994) show that the covariance structure of money, output, and prices seems to depend'on whether a country is on a fiat or commodity money standard. Within a fiat money regime, Friedman and Kuttner (1992) use results from vector autoregressions to argue that a deterioration in nominal-real relationships followed the Federal Reserve's policy change in 1979:IIIQ.

3. See Ostle (1963), pp. 225-227, for a detailed description of the test statistic used.

4. One could also let the trade-off be a function of expenditures. Since hours and consumption have a fairly high correlation, that modification would increase the amplitude of the price level. Thus, abstracting from it gives a conservative estimate of the amount of velocity and price-level volatility accounted for. Finally, one could let transactions require the use of physical resources rather than time, as is done in Sims (1989). While that is not unreasonable, the view here is that time is the main resource expended in the act of carrying out the transactions involved in this environment. 


\section{References}

Backus, David K. and Patrick J. Kehoe. "International Evidence on the Historical Properties of Business Cycles," American Economic Review, vol. 82, no. 4 (September 1992), pp. 864-88.

Bryan, Michael F. and William T. Gavin. "A Different Kind of Money Illusion: The Case of Long and Variable Lags," Journal of Policy Modeling, vol. 16, no. 5 (1994), pp. 529-40.

Cooley, Thomas F. and Lee E. Ohanian. "The Cyclical Behavior of Prices," Journal of Monetary Economics, vol. 28 (1991), pp. 25-60.

Friedman, Benjamin M. and Kenneth N. Kuttner. "Money, Income, Prices, and Interest Rates," American Economic Review, vol. 82, no. 3 (June 1992), pp. 472-92.

Ghez, Gilbert R. and Gary S. Becker. The Allocation of Time and Goods over the Life Cycle. New York: Columbia University Press, 1975.

Kydland, Finn E. "Monetary Policy in Models with Capital," in F. van der Ploeg and A.J. de Zeeuw, eds., Dynamic Policy Games in Economies. Amsterdam: NorthHolland, 1989.

. "The Role of Money in a Business Cycle Model," Federal Reserve Bank of Minneapolis, Discussion Paper 23, revised February 1991.

and Edward C. Prescott. "Time to Build and Aggregate Fluctuations," Econometrica, vol. 50 (1982), pp. 1345-70.

and "Business Cycles: Real Facts and a Monetary Myth," Federal Reserve Bank of Minneapolis, Quarterly Review, vol. 14 (1990), pp. 3-18.

Neely, Chris, Amlan Roy, and Charles Whiteman. "Identification Failure in the Intertemporal Consumption CAPM," Federal Reserve Bank of St. Louis, unpublished manuscript, May 1995.

Ostle, Bernard. Statistics in Research. Ames, Iowa: Iowa University Press, 1963.

Prescott, Edward C. "Theory ahead of Business Cycle Measurement," CarnegieRochester Conference Series on Public Policy. New York: North-Holland, 1986. 
Rolnick, Arthur J. and Warren E. Weber. "Inflation, Money, and Output under Alternative Monetary Standards," Federal Reserve Bank of Minneapolis, Staff Report 175, July 1994.

Salemi, Michael K. "Revealed Preference of the Federal Reserve: Using Inverse Control Theory to Interpret the Policy Equation of a Vector Autoregression," Journal of Economic and Business Statistics, vol. 13, no. 4 (October 1995), pp. 419-33.

Sims, Christopher A. "Models and Their Uses," American Journal of Agricultural Economics, vol. 71, no. 2 (May 1989), pp. 489-94.

Smith, R. Todd. "The Cyclical Behavior of Prices," Journal of Money, Credit, and Banking, vol. 24, no. 4 (November 1992), pp. 413-30.

Wolf, Holger C. "Procyclical Prices: A Demi-Myth?” Federal Reserve Bank of Minneapolis, Quarterly Review, vol. 15 (Spring 1991), pp. 25-28 
Cyclical Behavior of U.S. Quarterly Data / Real Variables (Deviations from Trend)

\begin{tabular}{|c|c|c|c|c|c|c|c|c|c|c|c|c|}
\hline \multirow[b]{2}{*}{ Variable $x$} & \multirow{2}{*}{$\begin{array}{l}\text { Std. } \\
\text { Dev. }\end{array}$} & \multicolumn{11}{|c|}{ Correlations with RGDP from 1959: IQ to 1994 : IVQ } \\
\hline & & $x(t-5)$ & $x(t-4)$ & $x(t-3)$ & $x(t-2)$ & $x(t-1)$ & $x(t)$ & $x(t+1)$ & $x(t+2)$ & $x(t+3)$ & $x(t+4)$ & $x(t+5)$ \\
\hline $\begin{array}{l}\text { GDP in } 1987 \text { Dollars } \\
\text { (RGDP) }\end{array}$ & 1.62 & 0.05 & 0.25 & 0.46 & 0.68 & 0.86 & 1.00 & 0.86 & 0.68 & 0.46 & 0.25 & 0.05 \\
\hline Consumption & 1.23 & 0.27 & 0.45 & 0.62 & 0.77 & 0.87 & 0.88 & 0.73 & 0.54 & 0.33 & 0.10 & -.09 \\
\hline Durables & 5.00 & 0.34 & 0.48 & 0.59 & 0.71 & 0.78 & 0.80 & 0.61 & 0.40 & 0.18 & -.04 & -.22 \\
\hline $\begin{array}{l}\text { Nondurables and } \\
\text { Services }\end{array}$ & 0.83 & 0.18 & 0.38 & 0.57 & 0.73 & 0.84 & 0.86 & 0.74 & 0.59 & 0.40 & 0.19 & 0.01 \\
\hline $\begin{array}{l}\text { Private Domestic } \\
\text { Investment }\end{array}$ & 7.72 & 0.14 & 0.29 & 0.46 & 0.63 & 0.79 & 0.91 & 0.76 & 0.55 & 0.31 & 0.08 & -.15 \\
\hline Fixed Investment & 5.63 & 0.15 & 0.32 & 0.50 & 0.68 & 0.83 & 0.90 & 0.81 & 0.63 & 0.42 & 0.19 & -.03 \\
\hline $\begin{array}{l}\text { Hours Worked } \\
\text { (Estab.) }\end{array}$ & 1.54 & -.19 & -.01 & 0.19 & 0.42 & 0.67 & 0.88 & 0.92 & 0.86 & 0.73 & 0.56 & 0.37 \\
\hline $\begin{array}{l}\text { Productivity } \\
\text { (RGDP/Hours Worked) }\end{array}$ & 0.80 & 0.47 & 0.54 & 0.55 & 0.56 & 0.47 & 0.35 & -.01 & -.26 & -.48 & -.58 & -.59 \\
\hline
\end{tabular}

Source: Authors' calculations. 
Table 2

Cyclical Behavior of U.S. Quarterly Data / Nominal Variables and Velocity (Deviations from Trend)

\begin{tabular}{|c|c|c|c|c|c|c|c|c|c|c|c|c|}
\hline \multirow[t]{2}{*}{ Variable $x$} & \multirow{2}{*}{$\begin{array}{l}\text { Std. } \\
\text { Dev. }\end{array}$} & \multicolumn{11}{|c|}{ Correlations with RGDP from 1959: IQ to 1994: IVQ } \\
\hline & & $x(t-5)$ & $x(t-4)$ & $x(t-3)$ & $x(t-2)$ & $x(t-1)$ & $x(t)$ & $x(t+1)$ & $x(t+2)$ & $x(t+3)$ & $x(t+4)$ & $x(t+5)$ \\
\hline GDP Deflator & 0.87 & -.57 & -.65 & -.71 & -.72 & -.67 & -.58 & -.46 & -.33 & -.18 & -.04 & 0.10 \\
\hline CPI & 1.42 & -.60 & -.71 & -.76 & -.77 & -.71 & -.59 & -.42 & -.26 & -.07 & 0.11 & 0.27 \\
\hline Monetary Base & 0.88 & 0.11 & 0.20 & 0.26 & 0.32 & 0.37 & 0.38 & 0.34 & 0.29 & 0.22 & 0.14 & 0.09 \\
\hline M1 & 1.94 & 0.24 & 0.30 & 0.35 & 0.39 & 0.38 & 0.31 & 0.20 & 0.10 & 0.01 & -.05 & -.07 \\
\hline M2 & 1.38 & 0.40 & 0.51 & 0.59 & 0.62 & 0.58 & 0.45 & 0.26 & 0.08 & -.09 & -.25 & -.37 \\
\hline Base Velocity & 1.40 & -.35 & -.24 & -.08 & 0.13 & 0.34 & 0.55 & 0.50 & 0.39 & 0.28 & 0.18 & 0.07 \\
\hline M1 Velocity & 2.29 & -.38 & 0.32 & -.25 & -.13 & 0.03 & 0.22 & 0.26 & 0.26 & 0.24 & 0.20 & 0.14 \\
\hline M2 Velocity & 1.71 & -.56 & -.51 & -.41 & -.23 & 0.01 & 0.29 & 0.37 & 0.40 & 0.41 & 0.42 & 0.40 \\
\hline
\end{tabular}


Table 3

Cyclical Behavior of Real Variables in Subperiods

\begin{tabular}{|c|c|c|c|c|c|c|c|c|c|c|c|c|}
\hline \multirow[t]{2}{*}{ Variable $x$} & \multirow{2}{*}{$\begin{array}{l}\text { Std. } \\
\text { Dev. }\end{array}$} & \multicolumn{11}{|c|}{ Correlations with RGDP from 1959: IQ to 1979: IIIQ } \\
\hline & & $x(t-5)$ & $x(t-4)$ & $x(t-3)$ & $x(t-2)$ & $x(t-1)$ & $x(t)$ & $x(t+1)$ & $x(t+2)$ & $x(t+3)$ & $x(t+4)$ & $x(t+5)$ \\
\hline Real GDP & 1.67 & 0.03 & 0.24 & 0.46 & 0.69 & 0.86 & 1.00 & 0.86 & 0.68 & 0.45 & 0.22 & -.01 \\
\hline Consumption & 1.26 & 0.19 & 0.40 & 0.59 & 0.78 & 0.87 & 0.89 & 0.74 & 0.54 & 0.30 & 0.02 & -.21 \\
\hline Durables & 5.18 & 0.29 & 0.46 & 0.58 & 0.72 & 0.80 & 0.83 & 0.67 & 0.45 & 0.20 & -.07 & -.28 \\
\hline Nondur. \& Serv. & 0.86 & 0.10 & 0.31 & 0.53 & 0.73 & 0.83 & 0.84 & 0.73 & 0.56 & 0.35 & 0.09 & -.14 \\
\hline Pvt. Dom. Invest. & 7.78 & 0.14 & 0.29 & 0.46 & 0.64 & 0.78 & 0.91 & 0.76 & 0.57 & 0.34 & 0.11 & -.15 \\
\hline Fixed Investment & 5.87 & 0.13 & 0.31 & 0.50 & 0.70 & 0.83 & 0.89 & 0.79 & 0.62 & 0.41 & 0.17 & -.07 \\
\hline Hours (Estab.) & 1.58 & -.23 & -.06 & 0.16 & 0.39 & 0.63 & 0.85 & 0.92 & 0.86 & 0.74 & 0.56 & 0.34 \\
\hline \multirow[t]{3}{*}{ Productivity } & 0.89 & 0.45 & 0.54 & 0.57 & 0.60 & 0.51 & 0.38 & 0.00 & -.24 & -.48 & -.59 & -.61 \\
\hline & Std. & \multicolumn{11}{|c|}{ Correlations with RGDP from 1979: IVQ to 1994: IVQ } \\
\hline & & $x(t-5)$ & $x(t-4)$ & $x(t-3)$ & $x(t-2)$ & $x(t-1)$ & $x(t)$ & $x(t+1)$ & $x(t+2)$ & $x(t+3)$ & $x(t+4)$ & $x(t+5)$ \\
\hline Real GDP & 1.56 & 0.07 & 0.26 & 0.45 & 0.64 & 0.87 & 1.00 & 0.87 & 0.67 & 0.47 & 0.30 & 0.14 \\
\hline Consumption & 1.18 & 0.38 & 0.53 & 0.64 & 0.74 & 0.86 & 0.87 & 0.71 & 0.54 & 0.37 & 0.22 & 0.07 \\
\hline Durables & 4.72 & 0.41 & 0.52 & 0.60 & 0.67 & 0.74 & 0.74 & 0.52 & 0.34 & 0.14 & 0.00 & -.14 \\
\hline Nondur. \& Serv. & 0.80 & 0.31 & 0.49 & 0.61 & 0.71 & 0.85 & 0.88 & 0.77 & 0.62 & 0.48 & 0.34 & 0.21 \\
\hline Pvt. Dom. Invest. & 7.63 & 0.12 & 0.26 & 0.43 & 0.60 & 0.80 & 0.91 & 0.77 & 0.50 & 0.26 & 0.04 & -.16 \\
\hline Fixed Investment & 5.22 & 0.18 & 0.34 & 0.48 & 0.65 & 0.84 & 0.93 & 0.83 & 0.65 & 0.43 & 0.23 & 0.02 \\
\hline Hours (Estab.) & 1.54 & -.14 & 0.05 & 0.24 & 0.46 & 0.73 & 0.91 & 0.93 & 0.85 & 0.72 & 0.57 & 0.40 \\
\hline Productivity & 0.66 & 0.52 & 0.53 & 0.51 & 0.46 & 0.39 & 0.29 & -.06 & -.33 & -.51 & -.58 & -.59 \\
\hline
\end{tabular}

Source: Authors' calculations. 
Table 4

Cyclical Behavior of Nominal Variables and Velocity in Subperiods

\begin{tabular}{|c|c|c|c|c|c|c|c|c|c|c|c|c|}
\hline \multirow[b]{2}{*}{ Variable $x$} & \multirow{2}{*}{$\begin{array}{l}\text { Std. } \\
\text { Dev. }\end{array}$} & \multicolumn{11}{|c|}{ Correlations with RGDP from 1959: IQ to 1979: IIIQ } \\
\hline & & $x(t-5)$ & $x(t-4)$ & $x(t-3)$ & $x(t-2)$ & $x(t-1)$ & $x(t)$ & $x(t+1)$ & $x(t+2)$ & $x(t+3)$ & $x(t+4)$ & $x(t+5)$ \\
\hline GDP Deflator & 0.78 & -.41 & -.52 & -.66 & -.74 & -.72 & -.65 & -.55 & -.42 & -.23 & -.04 & 0.18 \\
\hline CPI & 1.38 & -.49 & -.67 & -.81 & -.86 & -.83 & -.74 & -.57 & -.38 & -.16 & 0.09 & 0.30 \\
\hline Monetary Base & 0.69 & -.21 & -.12 & 0.00 & 0.15 & 0.32 & 0.46 & 0.54 & 0.58 & 0.53 & 0.44 & 0.35 \\
\hline M1 & 0.94 & -.16 & 0.03 & 0.28 & 0.52 & 0.65 & 0.71 & 0.67 & 0.56 & 0.41 & 0.27 & 0.11 \\
\hline M2 & 1.63 & 0.45 & 0.61 & 0.73 & 0.78 & 0.76 & 0.64 & 0.45 & 0.20 & -.04 & -.28 & -.46 \\
\hline Base Velocity & 1.07 & -.10 & 0.07 & 0.24 & 0.44 & 0.61 & 0.79 & 0.60 & 0.40 & 0.23 & 0.09 & -.07 \\
\hline M1 Velocity & 0.96 & -.11 & -.04 & -.01 & 0.09 & 0.27 & 0.51 & 0.39 & 0.29 & 0.20 & 0.11 & 0.03 \\
\hline M2 Velocity & 1.59 & -.62 & -.63 & -.59 & -.44 & -.23 & 0.07 & 0.17 & 0.29 & 0.39 & 0.49 & 0.55 \\
\hline \multirow[t]{2}{*}{ Variable $x$} & \multirow[t]{2}{*}{$\begin{array}{l}\text { Std. } \\
\text { Dev. }\end{array}$} & \multicolumn{11}{|c|}{ Correlations with RGDP from 1979: IVQ 1994: IVQ } \\
\hline & & $x(t-5)$ & $x(t-4)$ & $x(t-3)$ & $x(t-2)$ & $x(t-1)$ & $x(t)$ & $x(t+1)$ & $x(t+2)$ & $x(t+3)$ & $x(t+4)$ & $x(t+5)$ \\
\hline GDP Deflator & 0.97 & -.78 & -.84 & -.81 & -.72 & -.63 & -.50 & -.36 & -.24 & -.13 & -.04 & .02 \\
\hline CPI & 1.43 & -.78 & -.78 & -.71 & -.64 & -.55 & -.38 & -.21 & -.08 & 0.04 & 0.14 & 0.22 \\
\hline Monetary Base & 1.10 & 0.44 & 0.54 & 0.55 & 0.51 & 0.46 & 0.34 & 0.19 & 0.09 & 0.02 & -.04 & -.06 \\
\hline M1 & 2.82 & 0.51 & 0.51 & 0.47 & 0.42 & 0.33 & 0.18 & 0.02 & -.09 & -.15 & -.18 & -.16 \\
\hline M2 & 0.94 & 0.28 & 0.28 & 0.25 & 0.22 & 0.14 & -.04 & -.18 & -.21 & -.21 & -.23 & -.23 \\
\hline Base Velocity & 1.82 & -.62 & -.55 & -.38 & -.15 & 0.13 & 0.40 & 0.45 & 0.40 & 0.33 & 0.26 & 0.17 \\
\hline M1 Velocity & 3.40 & -.61 & -.55 & -.42 & -.26 & -.06 & 0.17 & 0.28 & 0.31 & 0.31 & 0.27 & 0.20 \\
\hline M2 Velocity & 1.90 & -.48 & -.35 & -.17 & 0.05 & 0.33 & 0.60 & 0.63 & 0.54 & 0.44 & 0.34 & 0.24 \\
\hline
\end{tabular}

Source: Authors' calculations. 
Table 5. Tests for S tability of R ealV ariab les

Chi-square test for equality of correlations across sam ple periods (break in 1979 :IIIQ )

\begin{tabular}{|c|c|c|c|c|c|c|c|c|c|c|c|}
\hline V ariab le $x$ & $x(t-5)$ & $x(t-4)$ & $x(t-3)$ & $x(t-2)$ & $x(t-1)$ & $x(t)$ & $x(t+1)$ & $x(t+2)$ & $x(t+3)$ & $x(t+4)$ & $x(t+5)$ \\
\hline Consum ption & $\begin{array}{l}1.30 \\
(6.12)\end{array}$ & $\begin{array}{c}0.99 \\
(5.77)\end{array}$ & $\begin{array}{l}0.23 \\
(5.59)\end{array}$ & $\begin{array}{l}0.20 \\
(6.52)\end{array}$ & $\begin{array}{l}0.11 \\
(8.36)\end{array}$ & $\begin{array}{l}0.16 \\
(9.05)\end{array}$ & $\begin{array}{c}0.13 \\
(6.04)\end{array}$ & $\begin{array}{l}0.00 \\
(5.31)\end{array}$ & $\begin{array}{l}0.19 \\
(5.40)\end{array}$ & $\begin{array}{l}1.29 \\
(6.16)\end{array}$ & $\begin{array}{l}2.55 \\
(6.80)\end{array}$ \\
\hline D urables & $0.64(5.91)$ & $0.23(5.96)$ & $0.01 \quad(6.67)$ & $0.29(7.64)$ & 0.69 (8.37) & $1.94(7.44)$ & $1.70(5.01)$ & $0.52(4.41)$ & $0.10(4.78)$ & $0.15(5.10)$ & $\begin{array}{l}0.62 \\
(5.51)\end{array}$ \\
\hline $\begin{array}{l}\text { N ondurs.\& } \\
\text { Services }\end{array}$ & $\begin{array}{l}1.63 \\
(5.68)\end{array}$ & $\begin{array}{l}1.44 \\
(5.32)\end{array}$ & $\begin{array}{l}0.40 \\
(4.96)\end{array}$ & $\begin{array}{c}0.07 \\
(587)\end{array}$ & & $\begin{array}{c}0.56 \\
(10.15)\end{array}$ & & $\begin{array}{l}0.29 \\
(7.64)\end{array}$ & & $\begin{array}{l}2.40 \\
(7.87)\end{array}$ & \\
\hline Inves & $\begin{array}{l}0.01 \\
(5.82)\end{array}$ & $\begin{array}{l}0.03 \\
(6.10)\end{array}$ & $\begin{array}{l}0.06 \\
(5.76)\end{array}$ & $\begin{array}{l}0.14 \\
(6.10)\end{array}$ & $\begin{array}{l}0.11 \\
(6.95)\end{array}$ & $\begin{array}{l}0.01 \\
(9.25)\end{array}$ & $\begin{array}{l}0.01 \\
(4.82)\end{array}$ & $\begin{array}{l}0.32 \\
(3.07)\end{array}$ & $\begin{array}{l}0.24 \\
(3.00)\end{array}$ & $\begin{array}{l}0.15 \\
(3.21)\end{array}$ & $\begin{array}{l}0.01 \\
(3.62)\end{array}$ \\
\hline Fixed Investm ent & $\begin{array}{l}0.08 \\
(6.86)\end{array}$ & $\begin{array}{c}0.03 \\
(6.68)\end{array}$ & $\begin{array}{l}0.01 \\
(7.47)\end{array}$ & $\begin{array}{l}0.26 \\
(7.71)\end{array}$ & $\begin{array}{l}0.09 \\
(9.45)\end{array}$ & $\begin{array}{c}1.93 \\
(12.71)\end{array}$ & $\begin{array}{l}0.45 \\
(7.95)\end{array}$ & $\begin{array}{l}0.08 \\
(5.47)\end{array}$ & $\begin{array}{l}0.04 \\
(4.65)\end{array}$ & $\begin{array}{l}0.13 \\
(4.56)\end{array}$ & $\begin{array}{l}0.26 \\
(5.32)\end{array}$ \\
\hline Hours (Estab .) & $\begin{array}{l}0.23 \\
(6.22)\end{array}$ & $\begin{array}{l}0.39 \\
(6.18)\end{array}$ & $\begin{array}{l}0.23 \\
(5.80)\end{array}$ & $\begin{array}{l}0.24 \\
(5.22)\end{array}$ & $\begin{array}{l}1.07 \\
(4.51)\end{array}$ & $\begin{array}{l}2.98 \\
(5.61)\end{array}$ & $\begin{array}{l}0.51 \\
(9.07)\end{array}$ & $\begin{array}{l}0.07 \\
(9.49)\end{array}$ & $\begin{array}{l}0.10 \\
(7.88)\end{array}$ & $\begin{array}{l}0.00 \\
(6.99)\end{array}$ & $\begin{array}{l}0.18 \\
(6.67)\end{array}$ \\
\hline Produ & $\begin{array}{l}0.25 \\
(9.69)\end{array}$ & $\begin{array}{l}0.01 \\
(8.40)\end{array}$ & $\begin{array}{l}0.26 \\
(6.80)\end{array}$ & $\begin{array}{l}1.20 \\
(5.31)\end{array}$ & $\begin{array}{l}0.77 \\
(4.87)\end{array}$ & $\begin{array}{l}0.35 \\
(4.85)\end{array}$ & $\begin{array}{l}0.12 \\
(3.76)\end{array}$ & $\begin{array}{l}0.31 \\
(4.21)\end{array}$ & $\begin{array}{l}0.06 \\
(5.77)\end{array}$ & $\begin{array}{l}0.00 \\
(6.63)\end{array}$ & $\begin{array}{l}0.05 \\
(7.07)\end{array}$ \\
\hline
\end{tabular}

$\mathrm{N}$ ote: Shading indicates that the Wald statistic rejects stability assum ing the asym totic $10 \%$ critical value, 2.71 . Sim ulated $10 \%$ critical values are show $n$ in parentheses. Source: A uthors' calculations. 
Table 6. Tests for Stability of Nominal Variables

Chi-square test for equality of correlations across sample periods (break in 1979:IIIQ)

\begin{tabular}{|c|c|c|c|c|c|c|c|c|c|c|c|}
\hline Variable $\mathrm{x}$ & $x(t-5)$ & $x(t-4)$ & $x(t-3)$ & $x(t-2)$ & $x(t-1)$ & $x(t)$ & $x(t+1)$ & $x(t+2)$ & $x(t+3)$ & $x(t+4)$ & $x(t+5)$ \\
\hline GDP & 12.14 & 13.84 & 3.58 & 0.03 & 1.05 & 1.74 & 1.88 & 1.25 & 0.41 & 0.00 & 0.80 \\
\hline Deflator & $(9.59)$ & (10.33) & (10.76) & (11.10) & (11.94) & (11.87) & (10.39) & $(9.04)$ & $(8.06)$ & (7.64) & $(7.42)$ \\
\hline \multirow[t]{2}{*}{ CPI } & 8.61 & 1.87 & 1.84 & 8.97 & 10.65 & 9.76 & 6.28 & 3.47 & 1.31 & 0.08 & 0.26 \\
\hline & $(7.08)$ & (7.37) & $(9.70)$ & (12.46) & (10.89) & $(8.67)$ & $(6.56)$ & $(5.83)$ & $(6.05)$ & $(6.66)$ & (7.06) \\
\hline Monetary & 15.17 & 16.84 & 12.64 & 5.70 & 0.97 & 0.69 & 5.62 & 10.74 & 10.80 & 8.62 & 6.06 \\
\hline Base & (7.39) & $(6.72)$ & $(6.38)$ & (7.03) & $(7.24)$ & $(8.02)$ & $(7.83)$ & $(8.65)$ & (9.28) & $(9.56)$ & (10.43) \\
\hline \multirow[t]{2}{*}{ M1 } & 16.64 & 9.39 & 1.69 & 0.51 & 6.04 & 17.08 & 21.06 & 17.21 & 11.68 & 6.65 & 2.40 \\
\hline & $(6.93)$ & $6.13)$ & $(5.92)$ & (6.89) & $(7.75)$ & $(7.60)$ & $(7.46)$ & $(8.02)$ & $(9.15)$ & $(9.19)$ & $(8.81)$ \\
\hline \multirow[t]{2}{*}{ M2 } & 1.22 & 5.51 & 14.85 & 23.08 & 24.05 & 21.68 & 14.60 & 5.95 & 0.94 & 0.08 & 2.29 \\
\hline & $(8.75)$ & $(8.76)$ & (10.17) & (11.60) & $(10.12)$ & $(7.84)$ & $(6.74)$ & $(6.86)$ & $(7.85)$ & $(9.50)$ & (10.48) \\
\hline
\end{tabular}

Tests for Stability of Velocity

Chi-square test for equality of correlations across sample periods (break in 1979:IIIQ)

\begin{tabular}{|c|c|c|c|c|c|c|c|c|c|c|c|}
\hline Variable $\mathrm{x}$ & $x(t-5)$ & $x(t-4)$ & $x(t-3)$ & $x(t-2)$ & $\mathrm{x}(\mathrm{t}-1)$ & $x(t)$ & $x(t+1)$ & $x(t+2)$ & $x(t+3)$ & $x(t+4)$ & $x(t+5)$ \\
\hline Base & 12.57 & 15.21 & 13.61 & 12.91 & 11.07 & 13.79 & 1.46 & 0.00 & 0.43 & 1. & 1.87 \\
\hline Velocity & $(7.85)$ & (7.92) & $(7.55)$ & $(6.69)$ & $(6.48)$ & (8.67) & $(4.91)$ & $(4.46)$ & $(5.05)$ & $(4.98)$ & $(4.54)$ \\
\hline M1 Velocity & $\begin{array}{c}11.46 \\
(7.16)\end{array}$ & $\begin{array}{l}10.57 \\
(6.68)\end{array}$ & $\begin{array}{c}6.17 \\
(7.67)\end{array}$ & $\begin{array}{c}4.40 \\
(6.90)\end{array}$ & $\begin{array}{l}3.81 \\
(6.06)\end{array}$ & $\begin{array}{c}5.03 \\
(7.80)\end{array}$ & $\begin{array}{c}0.47 \\
(6.71)\end{array}$ & $\begin{array}{c}0.02 \\
(5.67)\end{array}$ & $\begin{array}{c}0.50 \\
(6.08)\end{array}$ & $\begin{array}{c}0.96 \\
(5.92)\end{array}$ & $\begin{array}{c}1.00 \\
(5.84)\end{array}$ \\
\hline M2 Velocity & $\begin{array}{c}1.35 \\
(10.28)\end{array}$ & $\begin{array}{c}4.27 \\
(10.29)\end{array}$ & $\begin{array}{c}8.25 \\
(9.17)\end{array}$ & $\begin{array}{c}9.10 \\
(8.02)\end{array}$ & $\begin{array}{c}10 . \\
(7.19)\end{array}$ & $\begin{array}{c}12.95 \\
(8.67)\end{array}$ & $\begin{array}{l}10.94 \\
(8.78)\end{array}$ & $\begin{array}{c}3.23 \\
(8.24)\end{array}$ & $\begin{array}{c}0.10 \\
(9.53)\end{array}$ & $\begin{array}{c}1.01 \\
(10.20)\end{array}$ & $\begin{array}{c}4.48 \\
(10.89)\end{array}$ \\
\hline
\end{tabular}

Note: Shading indicates that the Wald statistic rejects stability assuming the asymtotic $10 \%$ critical value, 2.71 . Simulated $10 \%$ critical values are shown in parentheses.

Light shading indicates that stability is not rejected using the simulated critical values.

Source: Authors' calculations. 
Table 7. C yclicalB ehavior of Econom y w ith Fixed M oney Stock ${ }^{a}$

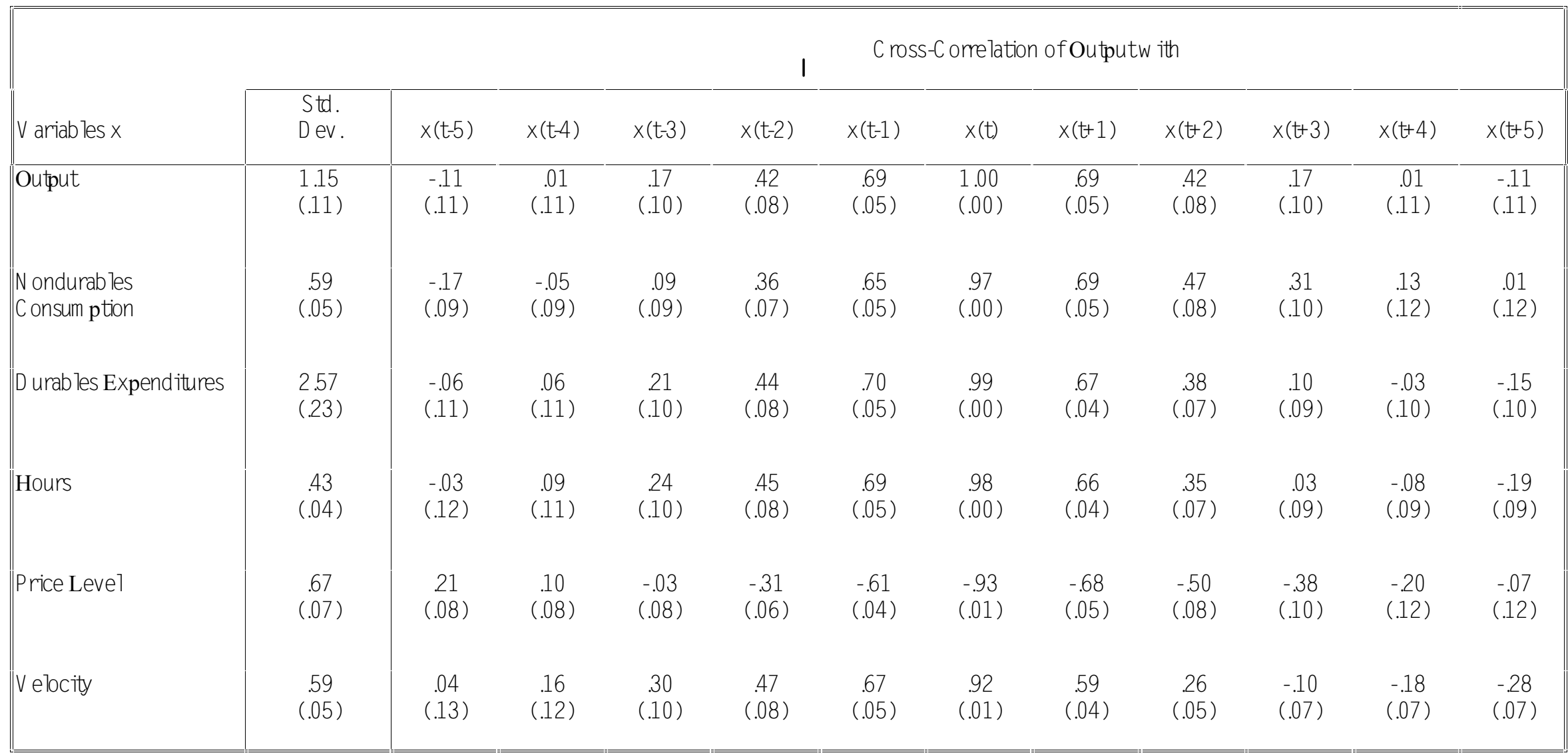

a These are the m eans of $50 \mathrm{~m}$ odel histories, each of w hich w as 144 periods long. The num bers in parentheses are standard deviations. Source: A uthors' calculations. 
Table 8. Cyclical Behavior under Altemative Specifications of the Money Supply Rule

$$
M_{t+1}-M_{t}=\nu_{0}+\nu_{1} Y_{t-1}+\nu_{2} M_{t}+\epsilon_{t}
$$

\begin{tabular}{|c|c|c|c|c|c|c|c|c|c|c|c|}
\hline Case & $\sigma_{\epsilon}$ & $v_{1}$ & $v_{2}$ & $\sigma_{p}$ & $\sigma_{p y}$ & $\sigma_{m}$ & $\sigma_{m y}$ & $\sigma_{\text {vel }}$ & $\sigma_{\mathrm{vel}, \mathrm{y}}$ & $\sigma_{\Delta \mathrm{p}, \mathrm{y}}$ & $\sigma_{\Delta \mathrm{m}, \Delta \mathrm{p}}$ \\
\hline I & 0 & 0 & 0 & .67 & -.93 & 0 & 0 & .59 & .92 & -.39 & 0 \\
\hline II & 0 & .10 & 0 & .94 & .96 & .38 & -.15 & 2.18 & 1.00 & .48 & -.29 \\
\hline III & 0 & .10 & -.05 & .47 & -.92 & .37 & .00 & .95 & .84 & -.36 & .25 \\
\hline IV & .6 & 0 & 0 & 1.11 & -.57 & .72 & -.02 & .85 & .61 & -.26 & .77 \\
\hline $\mathrm{V}$ & .6 & 0 & -.05 & .67 & -.93 & .73 & -.02 & .89 & .60 & -.39 & .11 \\
\hline VI & .6 & .10 & 0 & 1.22 & .73 & .82 & -.08 & 2.28 & .96 & .36 & .58 \\
\hline VII & .6 & .10 & -.05 & .48 & -.90 & .81 & -.01 & 1.15 & .69 & -.36 & .19 \\
\hline
\end{tabular}


Figure 1: Model Correlations Under Alternative Policy Responses to Output ${ }^{a}$

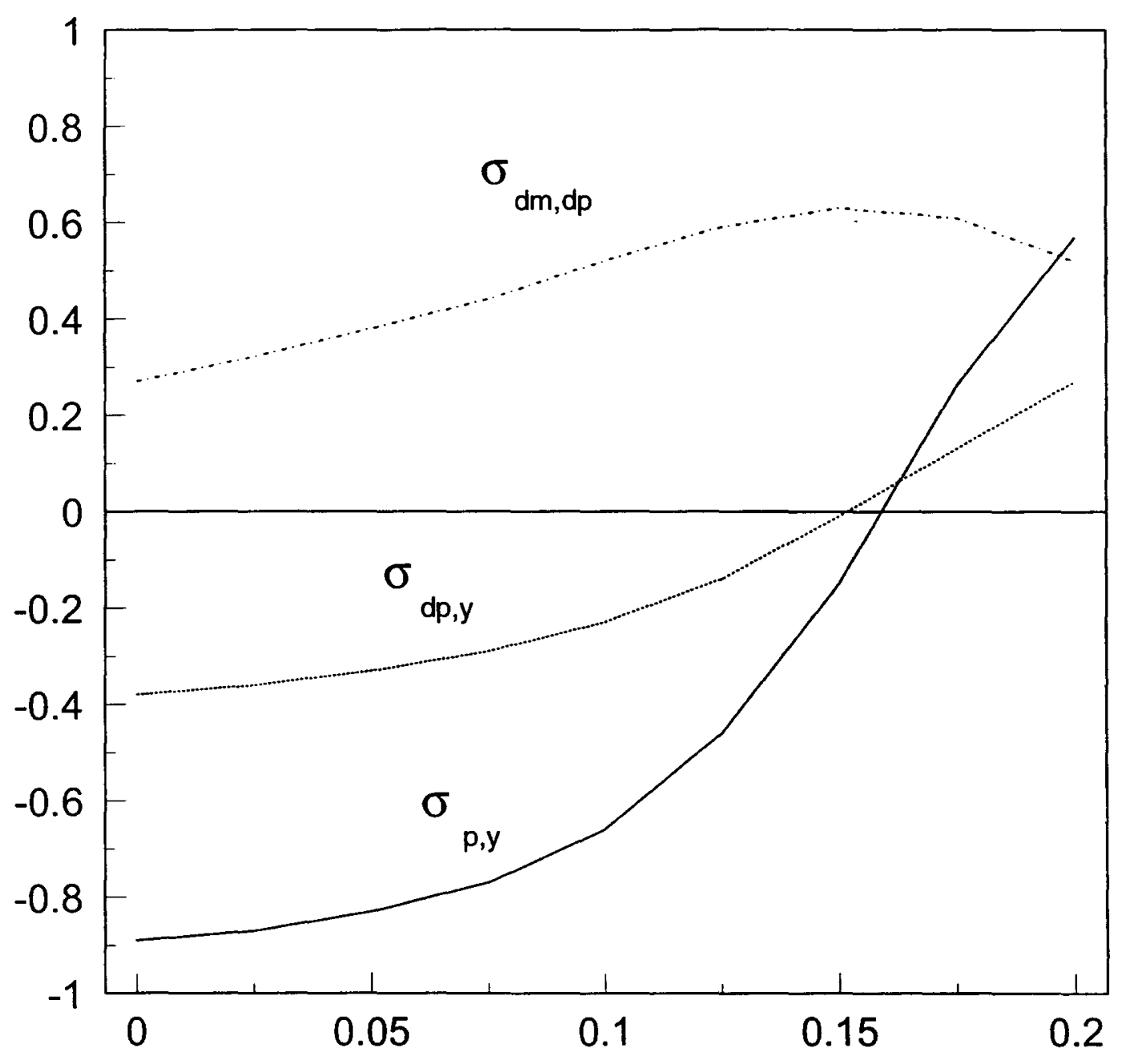

a In these experiments, the response to the money stock, $v_{2}$, was held constant at -0.02 .

Source: Authors' calculations. 
Figure 2: Model Correlations Under Alternative Policy Responses to the Money Stock ${ }^{a}$

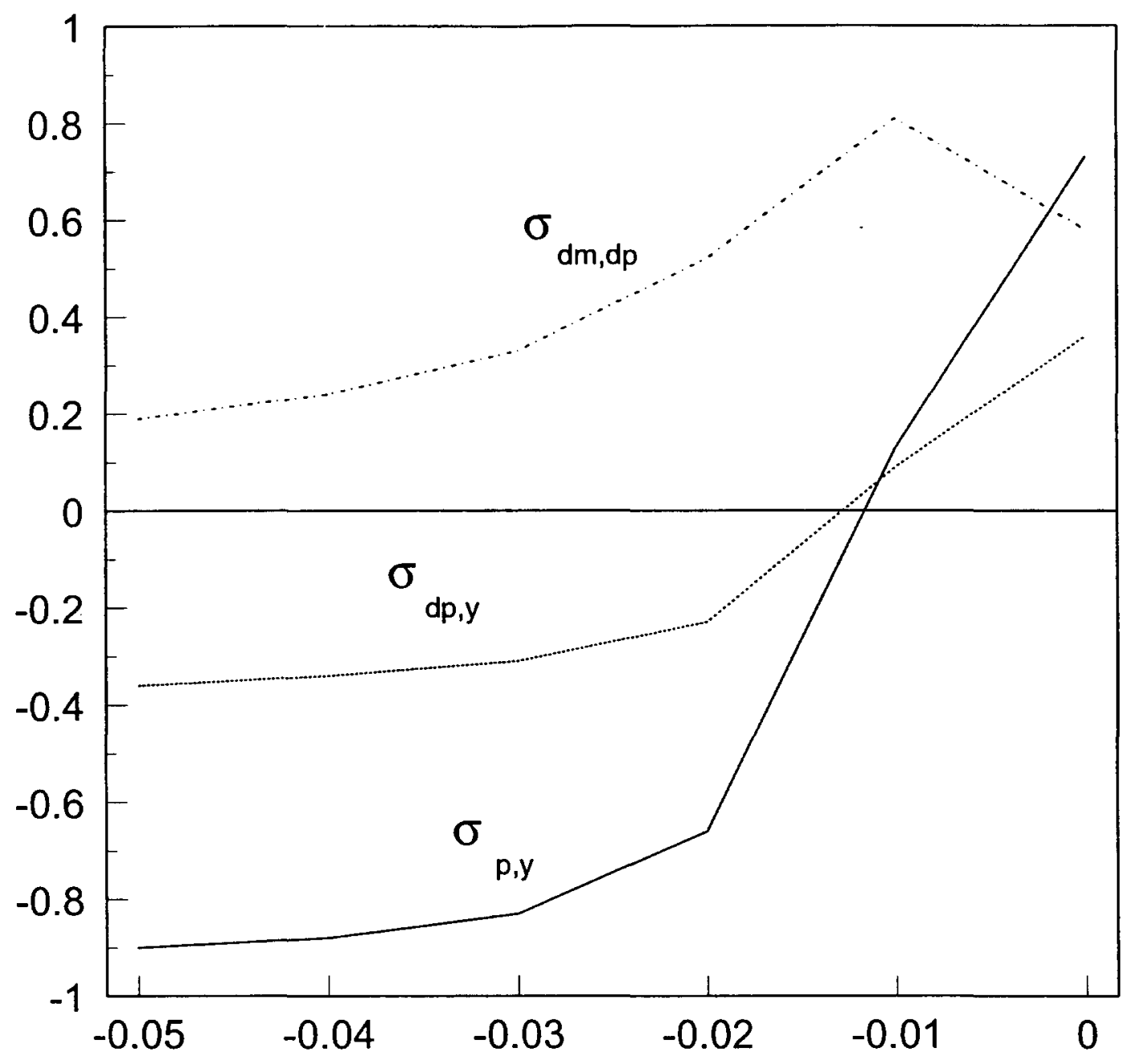

$a_{\text {In the }}$ thesperiments, the response to output, $v_{1}$, was held constant at 0.1 .

Source: Authors' calculations. 